\title{
OpenDocs

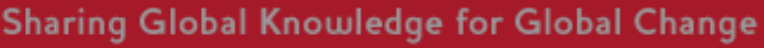

Title: Green grabs and biochar: Revaluing African soils and farming in the new carbon economy

Citation: Leach, M., J. Fairhead and J. Fraser, 2012, 'Green grabs and biochar: Revaluing African soils and farming in the new carbon economy', Journal of Peasant Studies, 39:2.

Official URL: http://www.tandfonline.com/doi/abs/10.1080/03066150.2012.658042

More details/abstract: Biochar currently attracts technological and market optimism, promising multiple wins - for climate change, food security, bioenergy and health - not least for African farmers. This paper examines the political-economic and discursive processes constructing biochar as a novel green commodity, creating new alliances amongst scientists, businesses, venture capital firms and non-governmental organisations. Carbon market logics are not only threatening large-scale land grabs for biochar feedstocks but also other forms of resource, labour and ecological appropriation through driving research and development and shaping small-scale pilot projects. In these, soil carbon is 'chopped out' of its ecosystem and social contexts and revalued as exchangeable pieces of carbon nature. Farmers are hailed as green actors and market winners, provided they discipline their practices according to these new technical and market logics. These discourses contrast strongly with the farmers' existing conceptual and practical repertoires; a case study from Liberia illustrates how farmers already manipulate soil carbon in creating locally valued anthropogenic dark earths, but within diverse farming repertoires, ontologies of human-nature interrelationship and historical and political ecologies.

Version: Submitted version (Author's Original Manuscript)

Terms of use: This is an Author's Original Manuscript of an article whose final and definitive form, the Version of Record, has been published in the JOURNAL OF PEASANT STUDIES, 2012, copyright Taylor \& Francis, available online at:

http://www.tandfonline.com/doi/abs/10.1080/03066150.2012.658042

This is a download from OpenDocs at the Institute of Development Studies

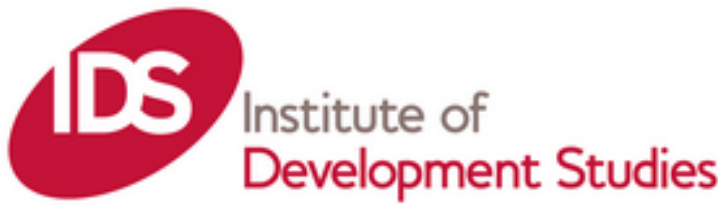




\title{
Green grabs and biochar: Revaluing African soils and farming in the new carbon economy
}

\author{
Melissa Leach, James Fairhead and James Fraser
}

Pre-final version of:

Leach, M., J. Fairhead and J. Fraser, 2012, 'Green grabs and biochar: Revaluing African soils and farming in the new carbon economy', Journal of Peasant Studies, 39:2.

\section{Introduction $^{1}$}

Biochar is a carbon-rich substance that is formed when biomass is burned under oxygen-deprived conditions. Recent research suggests that when incorporated into the highly weathered soils of the humid tropics, it can act as a soil 'conditioner', rendering poor soils more fertile by improving their water and nutrient dynamics (Lehmann and Joseph 2009). Biochar is thus attracting research and development attention as a route to support agricultural sustainability, food security and livelihoods for resource-poor farmers in Africa and beyond. During the last five years the idea of enriching soils with biochar has attracted extraordinary levels of technological optimism, entrepreneurial investment, and scientific inquiry and debate. Driving this is the promise not just that biochar might enhance soil fertility, but that it will also provide an important carbon sink. The carbon locked up in biochar resists decomposition with a half life of up to 1000 years (Kuzyakov et al. 2009), so its use as a soil conditioner would simultaneously sequester carbon in soils. Incorporating biochar into soils is thus a promising route to climate change mitigation as a geo-engineering (sometimes distinguished as 'biogenic') technology for carbon capture and storage (Royal Society 2009, Woolf et al. 2010).

High-profile public commentators are more than enthusiastic. As James Lovelock, the well known architect of the Gaia hypothesis, puts it:

There is one way we could save ourselves and that is through the massive burial of charcoal. It would mean farmers turning all their agricultural waste - which contains carbon that the plants have spent the summer sequestering - into non-biodegradable charcoal, and burying it in the soil. Then you can start shifting really hefty quantities of carbon out of the system and pull the CO2 down quite fast (Vince 2009, 1).

Or as Bill McKibben, author and climate activist, argues:

\footnotetext{
${ }^{1}$ This article draws on research funded by the UK Economic and Social Research Council (ESRC) through the grant 'Anthropogenic dark earths in Africa?' and the 'Biochar' project of the ESRC STEPS (Social, Technological and Environmental Pathways to Sustainability) Centre, and we gratefully acknowledge this financial support. Thanks are also due to Eliza Lehner who assisted with literature research, to the townspeople of Wenwuta, and to Jeanette Carter, Woulay Narmah and Victoria Frausin for their assistance and support during the Liberia case study. 
If you could continually turn a lot of organic material into biochar, you could, over time, reverse the history of the last two hundred years...We can, literally, start sucking some of the carbon that our predecessors have poured into the atmosphere down through our weeds and stalks and stick it back in the ground. We can run the movie backward. We can unmine some of the coal, undrill some of the oil. We can take at least pieces of the Earth and - this is something we haven't done for quite a while - leave them Better Than We Found Them (McKibben 2009, 1).

Elsewhere, biochar is described as:

..... the only true carbon *reductive* technology that exists... unique in its ability to help humanity solve the climate change problem by taking carbon *out* of the atmosphere. ...But this just scratches the surface of what we know about what biochar can do. Biochar is the Swiss Army knife, or the 'killer app' of climate solutions. It is the key to the New Carbon Economy (Kamsler 2011).

These quotes exemplify a discourse that constructs biochar as a quintessential technology of repair (Fairhead et al. infra); enabling tropical soil ecologies and their farming to act as a kind of 'super nature' - not only enhancing the sustainability of production on location but also sinking the carbon dioxide pollutant produced around the world. Moreover, to this 'win-win' of carbon sequestration and food security are added other benefits. The pyrolisation of biomass can, with the right technologies, produce biofuels and bioenergy, and because small-scale biochar production can apparently be achieved through reduced-smoke woodstoves, this could also improve women's health too. As Flannery $(2009, x x v)$ puts it: 'The biochar approach provides a uniquely powerful solution: it allows us to address food security, the fuel crisis and the climate problem, and all in an immensely practical manner'. Biochar is thus constructed as a powerful 'multiple win' technology - not least for small farmers in African settings.

In this article we examine how these discourses around the promise of biochar are generating new valuations of nature, in conjunction with an emerging political economy. We explore the implications for resource-poor farmers in African settings and the ecologies they inhabit, highlighting ways in which the promise of fantastic benefits also threatens to translate into land and resource appropriation, and the disciplining of farming practices in new and alienating ways. That biochar development might become a form of 'green grabbing' is a very real threat.

Current interest in biochar has in part developed from a new appreciation of anthropogenically improved soils in the Amazon, known as terra preta. These are highly fertile, carbon-enriched "anthropogenic dark earths" (ADE) that formed in otherwise very poor soils through the settlement and everyday practices of pre-Columbian Native Amazonian populations (Glaser and Birk 2011). As we show later, it is now suggested that the kind of carbon enrichment found in ADE (and perhaps able to be replicated in part through modern biochar technologies) could be transferred elsewhere - in particular to Africa (Sillitoe 2006). This perspective overlooks the possibility that smallholder farmers in Africa already produce and use ADE as part of their existing repertoire of knowledge and practices.

Our concern, and the arguments we develop here, have grown out of research which does find farmers to be producing and using ADE in West Africa (Fairhead and Leach 2009, Fairhead et al. 2009). Our recent studies in the forest and forest-savanna transition zones of Liberia, Sierra Leone, Guinea and Ghana are revealing the widespread presence of highly fertile ADE soils, analogous to Amazonian terra preta, yet subject to continuing production and use (ESRC ADE in Africa Project: forthcoming papers) We begin with a case study from Liberia which demonstrates how farmers have been adding multiple forms of biochar and organic material to certain soils over long periods of time, within broader livelihood and 
agro-ecological repertoires. The addition of charred carbon is one component among many others involved in the upgrading of soils into enduringly fertile, locally-valued anthropogenic dark earths. But as we sketch out, the production of ADE in Liberia is part and parcel of a diverse array of soil transforming practices, all embedded in social-ecological relations and histories.

Whilst biochar is important to these processes, research interest surrounding ADE has been reconfigured and reduced in much environment-development debate as an interest in 'biochar'. We go on to examine the emergence and effect of the biochar phenomenon in Africa and beyond, drawing on published literature, internet debate, project descriptions and media. We show how political-economic, discursive, social and science/policy processes are configuring, researching and developing biochar as a particular kind of green commodity in ways that contrast strongly with local understandings and practices around $A D E$, and which suggest a reductive interest in biochar that threatens to fuel green grabs.

First, we outline the context in which biochar has been constructed and seen as a solution to climate problems. This has given rise to heated debates about the appropriate scale for biochar interventions, and the source of their biomass feedstocks. Second, we consider the processes involved in constructing biochar as a marketable commodity. Those arguing the merits of biochar suggest a 'double profit' from improved soil fertility and from carbon trading cash. The promise of biochar and the allure of a lucrative carbon trading market for it is creating a mutually interested commercial community linking scientists, non-governmental organisations (NGOs), companies, consultancy and venture capital firms that will all benefit from the establishment of that market - and possibly also pass some of its profit to farmers. Lobbying for biochar to be incorporated into carbon trading locks it into a financialised world in which a plethora of firms is emerging and seeking to profit. By revealing the commodification and the 'businessification' of soil carbon, which enables it to become drawn into financialised markets, it becomes possible to discern how biochar becomes 'green grabbing' within processes that Harvey (2003) has characterised as 'accumulation by dispossession' (cf Fairhead et al. infra). Businessification skews revenue flows in the value chain towards the businesses operating the system, not to the farmers implementing it.

Third, we shall argue, the imperative to 'take biochar to market' is driving and disciplining the science conducted around it. The promise of biochar in the market is running far ahead of relevant agronomic, soil and ecological science, but it is also shaping that science. Research is being driven by the need for knowledge, standards and verification of the sequestered carbon's longevity in soil - by concerns with its durability, not fertility legacy. Academic interest in human-created 'dark earths', or terra preta as part of wider Amazonian historical ecology and more holistic understandings of soil-ecological transformation, are not drawn on in schemes to take biochar to the market, which tend to conflate terra preta with biochar. Biochar itself is fast becoming understood and researched as 'pure carbon'; a substance that can be applied to soil like a fertilizer and 'commensuralised' (Lohmann 2009) with carbon elsewhere within a carbon market.

Fourth, we show how these market logics and actors frame the pilot programmes now being implemented in African settings to make visible the technology's possibility, and to be poised to enact the market. Crucially, such pilots also enact a new disciplining of farmers, who become constructed as both 'green actors' and potential market winners provided they modify their farming practices according to new technical and market logics. By tracing how the shaping of science and the disciplining of farmers are rooted in the political and economic processes associated with 'accumulation by dispossession' we reveal a certain concordance between Foucaultian 'biopolitics' (Foucault 2008, Nally 2011) and Harvey's 
more Marxist political economy. This concordance presages major transformations of landscape, human-ecological and agrarian relations. The emergence of biochar shaped by the market for carbon puts into play a new structuring of relations in which farming is carried out. Within these, rather than benefit from the win-win of 'improved soil fertility' and 'financial flows from carbon markets', farmers will be 'labouring within the carbon industry' while others make profits from their assets. Green grabbing, we suggest, can be associated with such restructuring of resource and labour values, whether or not it also involves a simple grab of land.

\section{Anthropogenic Dark Earths - a Liberian case study}

Our research in Liberia, Guinea, Ghana and Sierra Leone has revealed the commonplace formation and use of anthropogenic dark earths (ADE). In a regional survey in Gbarpolu, Bong, Lofa and Nimba counties in Liberia we identified such African terra preta analogues at 134 locations, with dozens more reported. As a case study to discern how farmers identify, form, appreciate and use ADE we focused on the Loma town of Wenwuta in Southern Zorzor district, Lofa county, north-western Liberia. This is an old settlement, around 2 ha in size with a ring of anthropogenic dark earth (ADE) up to $1.80 \mathrm{~m}$ deep within and around it. Written accounts confirm that this town was thriving and four times its current size in the mid- nineteenth century (Fairhead et al 2003:132). We conducted structured and unstructured interviews, oral histories, transect walks and focus groups with informants in Wenwuta and surrounding villages and towns. Longitudinal quantitative surveys of trash disposal and biochar production, products sold in market and food consumption patterns were carried out. Ethnobotanical data were collected with transects, homegarden surveys and freelisting. Soil samples were taken from profile pits, along with composite samples from transects and homegardens.

Here we briefly summarise preliminary findings, which will be presented in detail elsewhere. We found that ADE form through additions of three primary forms of 'biochar': charred wood from fires lit for cooking, palm oil, soap, and potash production and blacksmiths' forges; charred palm kernel from oil production, charred organic byproducts from the production of potash (usually from the seed pods of Penthacletra macrophylla, Kola (Cola nitida), Silk Cotton (Ceiba pentandra) trees, and oil palm Elaeis guineensis fruit heads) and diverse organic material (e.g. rice stalks, old Raphia vinifera thatch and cooking waste) - along with excreta of people and animals and clay enrichment from house-building.

All of these materials are deposited around towns, villages and farm camps, which leads to the formation of rings of black, charcoal-rich, fertile anthropogenic soils. Viewed at the landscape level, these soils form a tripartite typology: type I forming in rings around current towns, villages and hamlets; type II forming in the soils underneath and around rice kitchens, and type III constituting relic anthrosols at the site of former settlements. Types I and III are typically between 0.5 and 2 ha in size, though two outliers were 5 ha and 14 ha respectively. Type II (rice kitchens) are usually $100-500 \mathrm{~m}^{2}$ in extent, but are much more abundant. Today, farmers cultivate settlement and kitchen types intensively as kitchen gardens or agroforests, incorporating plantain, banana, cocoa, kola and eddoe (Colocasia esculenta). Type I ADE is also 'mined' and used to plant seedlings, particularly oil palm While, in locations closer to the market, farmers sometimes bag ADE and sell it to agricultural extension agencies, more often than not they give it away for free. ADE on former settlement sites are used primarily as cocoa and kola agroforests.

Processes of ADE formation and cultivation are gendered. Apart from the charcoal from forges, additions of biochar are made entirely by women and young children who cook and process palm oils and potash. Women make other organic inputs from cooking and domestic refuse processing whereas 
men help dispose of larger refuse such as palm thatch. Whilst ADE are a by-product of everyday life, they are created by the labour of women who, after up to 10 years of waste deposition on a spot, burn the resulting pile, spread out the remains, and then cultivate them as homegardens. When women move their gardens onto newer middens, men typically plant the old kitchen gardens with tree crops, along with other non-domesticates such as silk cotton, Terminalia superba, and Albizia spp. Through the course of time, the resulting forest island may result in the town becoming 'too cold', whereupon it is abandoned, and planted over with tree crops. Thus ADE created and cultivated as kitchen gardens by women are often later used as agroforests by men. Tenurial rights to old town ADE are mediated by marriage to the daughters of the landowners.

Cocoa is the most significant and abundant crop grown on ADE today, planted there because of its enhanced fertility - in contrast with Liberia's otherwise heavily-leached, lateritic, very infertile upland soils. When cocoa is cultivated in natural soils in Liberia, these are lower down the soil catena and along streambanks. ADE sites therefore allow cultivation of cocoa in places where it would otherwise not be possible - indeed our preliminary survey suggests that up to $30 \%$ of Liberia's annual ca. 8,000 metric ton cocoa production may be produced on ADE. Cocoa production on ADE is also favoured by restrictions on tree-cutting and burning in old town spots, which normally feature ancestors' graves and sacred areas. These sites conserve diverse useful forest tree species, such as Funtumia elastica, Bosqueia angolensis, Ricinodendron heudelotii, Margaritaria discoidea, Terminalia superba, Pycnanthus angolensis, Ceiba pentandra, Sterculia tragacantha and Blighia sapida whose abundance differs significantly from those found on mature secondary forests in the region. Hence, the unique agronomic properties of ADE and culturally-oriented management practices work together to favour cocoa production and conserve certain useful tree species on type III ADE.

The processes that create these soils are part of agro-social-ecological relations, forming a historical political economy that encompasses relations with ancestors in old settlement sites. ADE formation in this Upper Guinea forest region is inextricably intertwined with population density and the social and political processes shaping it. In this region disparate social groups settle together within the central Mande cultural institution kEkE-daabe, which partitions the whole of society into '"wife-giving" and "wife-receiving" groups... above all perpetual relationships between landowners and latecomers' (Leopold, 1991). This and the turbulent pre-colonial and colonial history ensured that different town 'quarters' were conjoined and densely packed within large defensive walls, concentrating the deposition of biochar and organic and inorganic wastes. According to elders, more recently changes in social structure and warfare, rather than changes in subsistence technology, have reshaped ADE production. Until the 1950s, towns were dominated by a few chiefs, each of whom had many wives and controlled land tenure and the labour of women and young men. This meant large productive units which engaged in subsistence activities (e.g. farmed, cooked, made palm oil and potash) collectively. Today, productive units are much smaller, and households tend to resemble more nuclear families. Hence, subsistence activities are more individualized and dispersed, which both increases the production of char and organic materials and distributes ADE production through wider areas of the landscape. The recent war (1990-2003) has also transformed ADE production, because it caused many people to move their farm kitchens out of the town into the bush to hide them from marauding soldiers. This has had the effect of moving a significant proportion of ADE production out of the town into the bush, where people sometimes spend days or even weeks in their kitchens without returning to town.

While Loma people are aware that their actions produce ADE, the ultimate factors that shape continuity and change in its formation are sustained population density and similar subsistence technologies over time, while changes in social structure and warfare have increased ADE production and distributed it 
throughout the landscape. ADE formation and ownership is embedded in the politics of settlement processes and social relations, embodying the wife giver-receiver relationships that allowed strangers to settle land through creating kinship with those already there. The resulting anthropogenically-enriched sites are assets that represent both symbolic (ancestors' personhood in graves, sacred trees) and economic (fertile soils, cocoa agroforests) capital. Loma soil enrichment practices are thus part of diverse farming and everyday repertoires, embedded in ontologies of human-nature interrelationship, and are shaped by historical, political ecology.

In contrast, as we now go on to show, political-economic and discursive processes are now (re) constructing ADE as biochar, in far more reductionist ways. As biochar, soil carbon is discursively separated from these social-ecological processes to be presented as a solution to a climate change crisis, as a marketable commodity, as a subject of science driven by these interests, and as the focus of African pilot projects. Smallholder farmers and their practices figure in the ensuing debates - variously as potential victims, beneficiaries or new green enactors of biochar schemes - yet they and their practices appear in skeletalised forms that contrast sharply with the diverse, embedded relations and practices associated with ADE in places like Wenwuta.

\section{Climate crisis, carbon and the politics of scale}

The importance of technological as well as governance mechanisms to remove carbon from the atmosphere have recently come to the fore in policy discourses to address climate change (Royal Society 2009), and biochar is one such. When the late Peter Read of the Centre for Energy Research in New Zealand warned of dangerous climatic tipping points, he argued for large-scale carbon removals from the atmosphere, thrusting 'negative emissions systems, including, most promisingly, biochar, into a key role in climate change mitigation' (Read 2009, 395). Such views are echoed by James Hansen (head of the NASA Goddard Institute for Space Studies) who has argued that 'Replacing slash-and-burn agriculture with slash-and-char and use of agricultural and forestry wastes for biochar production would provide a CO2 drawdown of $~ 8$ ppm or more in half a century' (Hansen et al. 2008, 12). Tim Lenton, Professor in Earth System Science at University of East Anglia, calculates that biochar has the potential to sequester almost 400 billion tonnes of carbon by 2100 and to lower atmospheric carbon dioxide concentrations by 37 parts per million (Lenton and Vaughan 2009).

Worldwide, total soil organic carbon is estimated as twice that of the global atmospheric carbon pool (Denman et al 2007). Most soils already contain char generated through vegetation fires and settlement practices during the last few thousand years (e.g. Gonzalez-Perez et al 2004). Biochar scientists argue that biochar soil management offers the potential to add significantly to these pre-existing chars: For example Lehmann et al (2006) quote a potential global carbon sink of 5.5 to $9.5 \mathrm{GtC} /$ year by 2100 , larger than the annual quantity of carbon currently produced by fossil fuels.

These figures suppose an enormous growth in the resources and land areas devoted to the production of biochar feedstocks and that a high proportion of this would be converted to biochar. Discourses in support of such large-scale carbon capture therefore incorporate propositions about how this might be achieved. For example Goodall (2008), for whom biochar is one of his 'Ten Technologies to Save the Planet', proposes that 200 million hectares of forests, savannah and croplands could be turned into biochar plantations, replacing slow-growing species with fast-growing ones that enable an increased rate of carbon capture. Read advocated establishing up to 1 billion hectares of new tree plantations for biochar (Read 2009). Carbonscape, a company that hoped to be among the first to commercialise the technique, talks of planting 930 million hectares (Monbiot 2009a). 
Given competing uses of such land, heated debate has ensued over the appropriateness of large scale biochar production. In scientific circles, this is generally framed in terms of feasibility and sustainability. Thus the expert group contributing to The Royal Society's (2009) report concluded that sequestration rates sufficient for biochar to make a significant contribution to enhancing the global terrestrial carbon sink - generally taken as $1 \mathrm{GtC} /$ year - would be infeasible and unsustainable given competing land uses. Yet others have built models acknowledging land and biomass constraints with more positive implications (e.g. Amonette et al. 2007, Woolf et al. 2010). In public media and NGO circles, this debate over scale is framed more in terms of distribution and justice - asking whose land will produce biochar feedstocks. International NGOs, activist networks and journalists who have been vocal commentators on 'land grabbing' have brought biochar into this political and discursive domain. Thus the Biofuelwatch Declaration (TNI 2010) casts biochar and its new demands for biomass as 'a big new threat to people, land and ecosystems'. It is claimed that 'The negative impacts of large-scale biochar development in Africa are likely to be dramatic, including exacerbating land-grabbing' (African Biodiversity Network, Biofuelwatch and Gaia Foundation 2009). Critics are deeply critical of the visions of large biomass plantations envisaged by some of the most extreme advocates, which construct lands as marginal or empty, disregarding the myriad agricultural, pastoralist, collecting, and other livelihood activities carried out there. As the journalist Monbiot put it:

I wasn't harsh enough about Peter Read.... To him, people and land appear to be as fungible as counters in a board game. He makes the extraordinary assertion that "degraded land" - which he wants to cover with plantations - is uninhabited by subsistence farmers, pastoralists or hunters and gatherers. That must be news to all the subsistence farmers, pastoralists and hunters and gatherers I've met in such places (Monbiot 2009b, 1).

As these critics allude, the spectre of large-scale land deals to produce biochar feedstocks adds a new mechanism and dimension to the land grabs in Africa and elsewhere - driven by global food, fuel and financial crises, and often involving large foreign take-over deals (Cotula et al. 2009, Zoomers 2010). The implication is that land grabs for biochar are not just 'like' these other grabs, but could add to them, multiplying impacts on local communities and their access to land and resources, and exacerbating evictions, food insecurity and conflict. Thus foreign deals for biochar feedstock land threaten a re-run of 'biofuels vs. food' controversies and associated resource appropriations (Borras et al. 2010), yet with a new twist as 'carbon grabs' for biofuels and for biochar feedstocks threaten to compete with each other too. Second generation biofuel production envisages the use of wood (lignins), so land might be devoted to produce either feedstocks that will be pyrolised to produced biochar (perhaps liberating a little biofuel) or be turned wholesale into biofuel. A heavy emphasis on biochar might be seen to undermine the biofuel industry, but pursuing both raises the problem that land for biochar feedstocks and land for biofuels are both re-appropriated away from food production. Biochar could also add to other forms of 'green grabbing' for carbon sinks, as is suggested of some REDD+ schemes (McCarthy infra, Conant infra), as carbon markets drive private investment not only in establishing and protecting trees but also in producing charcoal.

Such large scale biochar land deals as yet remain a spectre, with little evidence of their materialisation on the ground. Others who are reacting against this dystopia less reject the technology, than argue that biochar could be made beneficial for small, rural farmers if technologies for the production and application of biochar on a small, local scale, from local biowaste, are developed and encouraged (Pratt and Moran 2010, Roberts et al. 2010, Lehmann and Joseph 2009). It is less a question of biochar's potential than of the way distributional issues shape how the technology is developed and promoted, 
and this could be in support of sustainable livelihoods for the poor. Small-scale systems based on the recycling of agricultural wastes can, it is argued, be fully compatible with local farming and resource control, while bringing soil fertility and rural development benefits (e.g. Reed 2009, 401). Pratt and Moran (2010) argue that small-scale biochar projects could be more efficient and cost-effective than large scale, mono-cultural biochar feedstock plantations, and that the spectre of land grabs suggested by biochar critics is an unhelpful distraction.

Cynical critics of this position see small-scale biochar as merely a step towards eventual, large-scale schemes and land grabs (African Biodiversity Network, Biofuelwatch and Gaia Foundation 2009). Biofuelwatch suggests that commercial organizations use images of small farmers to promote a 'humanitarian' image while actually seeking to implement the 'grand visions' that have been their interest from the outset (Smolker 2010).

\section{Taking biochar to market}

The debates over scale reveal that the distributional implications of emerging biochar technology will be influenced by multiple forces shaping technological innovation. We now examine how processes involved in constructing a market for biochar carbon are shaping the emergence of the technology and its distributional effects.

The aspiration that biochar might become incorporated into global carbon trading is animating a constellation of actors, from scientists and NGOs, to companies and venture capitalists. They are lobbying for biochar to become part of emerging carbon markets. Advocates are convinced that biochar can become 'a long-term and readily measurable sequestration product' that will provide additional revenue to those producing and incorporating it into the soil (Glover 2009, 378). Funding from carbon trading is argued to be essential to finance the research and development necessary to discover and exploit the full potential of biochar to contribute to climate change mitigation, and to enable scale-up to sequester carbon at globally-significant levels (Lal 2010). At the other end of the spectrum, those emphasizing small farmer livelihoods argue that if farmers receive payments for sequestered carbon, this can provide a new income stream and justify the financial and time investment necessary for them to adopt biochar systems (Palmer 2009). Through 'farming carbon' - sequestering carbon in soils, and selling carbon credits just like any other farm produced commodity - carbon trading could contribute to poverty reduction (Lal 2010). Glover (2009) lists numerous further opportunities for 'taking biochar to market', exploiting commercial demands across seemingly disparate areas from urban and rural waste management, agricultural input supply, livestock and industrial sectors, especially as these come under growing pressure from global climate change agendas to internalise environmental costs and use resources sustainably.

Currently the market for biochar carbon is only incipient. As markets and offset markets for carbon develop, exactly which modes of biogenic carbon capture might become embraced within them has become the focus of intense lobbying and negotiation. As the yearly round of Council of Parties of United Nations Framework Convention on Climate Change (UNFCCC) unfolds, the potential for including forest-sequestered carbon is growing as negotiations around Reducing Emissions from Deforestation and Degradation (REDD, and REDD+) in the UN Certified Emission Reductions (CER) scheme and Clean Development Mechanism (CDM) unfold. The potential of biochar for carbon sequestration, however, has redoubled attention to 'agricultural mitigation and adaptation opportunities.' Many organizations are lobbying negotiations to include agricultural activities (and within them, biochar). At present, 
whether this might be achieved by introducing agriculture into REDD+, or whether agriculture might included on its own account, is an open question. The growing emphasis on 'no climate security without food security' in UNFCCC negotiations, however, 'provide promise that biochar as a soil amendment will one day be recognized as a climate mitigation and adaptation technology' (IBI 2011, 1). Yet at present, major stumbling blocks concern standards and data availability - how to measure, report, and verify that biochar strategies have actually resulted in additional, and durable, carbon sequestration.

Even in the absence of formal UN carbon market recognition for biochar, opportunities already exist for carbon financing: first through voluntary carbon markets and a variety of available schemes not linked to the Kyoto Protocol and UNFCCC (Gaunt and Cowie 2009) and second through the practice and possibility of aggregating biochar projects with other kinds of small offset project to (legitimately and cost-effectively) sell them in formal global markets (Palmer 2009). For instance the World Bank has been encouraging and orchestrating rapidly-advancing market economies (including China, Chile, Indonesia and Mexico) to set up their own carbon markets, and its President has urged the inclusion of agricultural mitigation activities, including soil carbon sequestration, within them. Voluntary Carbon Standards methodologies are being developed for agriculture, and biochar advocates are seeking to develop related standards for biochar - especially around the stability of carbon in soil. In the United States, the International Biochar Initiative (IBI) succeeded in getting biochar research and development included in the 2008 United States Farm Bill while the 2009 US Senate Climate Bill features biochar prominently.

Whilst biochar is not yet within the market, its potential to join has generated strong alliances among those with research, policy and commercial interests. Commercial interests (and indeed scientific interests - including our own) stand to gain if biochar carbon can become tradeable. Lobbyists include international organizations and networks, notably the IBI, as well as a range of NGOs and of agribusiness and other companies seeking opportunities to invest in the new carbon economy. The 'Carbon War Room' established by business entrepreneur Richard Branson to harness 'the power of entrepreneurs to implement market-driven solutions to climate change' has, through its 'Operation Black Gold', sought to 'apply overwhelming force' to ensure that biochar is included in carbon trading schemes and gains prominence on the agendas of large NGOs (Smolker 2010). Tight networks link these science, policy and business actors and institutions, and they find common purpose in constructing the market. Many university researchers are on the boards of biochar organizations or companies, or offer biochar consulting services (see IBI 2010). The biochar community is also drawn together around projects, with scientists sometimes focusing their research on schemes that companies have instituted for profit - not unlike the links between research and business seen in the pharmaceutical industry. In these ways, it is reasonable to speak of a biochar-for-carbon-sequestration community or industry.

Networks are also facilitated through overarching international organizations. Central amongst these is the International Biochar Initiative (IBI), a 'non-profit organization that supports researchers, commercial entities, policy makers, development agents, farmers and gardeners, and others committed to sustainable biochar production and use' (IBI 2010,1) whose board unites members from key research and commercial organizations. Paid subscriptions entitle members to, inter alia, support IBI's work to commercialize biochar systems globally. The IBI sees itself as 'providing a face for biochar research and outreach efforts as the authoritative organization with respect to information and policy on biochar' (Lehmann and Joseph 2009: xxiv); not surprisingly given this self-proclaimed leading public face, it is also a key target of biochar's critics. Many smaller pro-biochar networks are also emerging, including national ones in China, Mongolia, Hawaii, New Zealand, Japan, and elsewhere. Some are overtly marketoriented, such as Biochar Europe, which unites companies and researchers 'to promote the development of a large-scale biochar industry within Europe', through research and development and 
by seeking carbon offsets through biochar to be recognised in emissions trading (Biochar Europe 2010, 1). Meanwhile the Indian-based TSBI (The Society of Biochar initiatives), whose founder in 2010 identified himself as 'a passionate earth child and geo-engineering initiator' (TSBI 2010, 1) exemplifies the wide range of subjectivities that the promise of biochar seems able to unite and reconcile.

The way biochar is conceived within these carbon market negotiations contrasts strongly with the farmers' understandings revealed in the Liberian case. Ecological-vegetation-soil processes are (re)valued in terms of a particular carbon product. 'Carbon buried in soils' becomes an exchangeable green commodity. In this sense lobbying for biochar to be incorporated into carbon trading both depends on, and reproduces, a 'financialisation' of carbon-related processes - bringing into the sphere of financial exchange phenomena that once lay outside it (Harvey 2003, see also Sullivan 2011). And whereas farmers' understandings and experiences are embedded in place and history, carbon trading, including the offsetting of emissions in one place through emissions reductions or carbon sinks in others, depends on processes of commensuration whereby a carbon molecule in one place is treated as equivalent to a carbon molecule anywhere else (Lohmann 2009).

\section{Biochar businesses and the political economy of promise}

Given the rich - if uncertain - rewards promised by future global carbon markets, businesses are rapidly emerging in this sector. The logic of business profit - or at least future, promised profit - is configuring how nascent forms of regulation are emerging around biochar, in an exemplar of what Harvey (2003) termed the 'businessification' of governance, in which there is a shift in emphasis from governance for people to governance for business.

The agronomic potential, the existing markets for biochar carbon, and the promise of big carbon trading gains to come has enticed many small companies and commercial initiatives into the arena. These are a subset of the large and growing array of commercial ventures forming around the new carbon economy in general. As the promotional website of venture capital firm VenEarth Group put it: 'Large scale deployment of biochar in agriculture can deliver gigatons of annual carbon sequestration while improving farm productivity, making us all healthier and wealthier' (VenEarth 2010, 1). Mantria Industries exemplifies something of the nature of the industry. It opened the 'world's first commercial scale BioChar facility' in August 2009 to great fanfare but no longer exists, having been charged for fraud by US government regulators for using 'exaggerated claims and aggressive marketing to con people into investing in biochar sequestration' (Inman 2010,1). It is a fast-moving world of promise, and businesses come and go.

Among those companies currently forming or shaping their activities and claims around the promise of biochar, are first, those producing biochar or biochar technology. For example BioChar Products is 'a start up company dedicated to the demonstrating and testing of the fast pyrolysis concept for use in small communities near forested landscapes' (Biochar Products 2010,1). Carbon Gold is a UK-based company that manufactures biochar-based products for gardening and has a portfolio of projects in developing countries. BiG (Black is Green) is an Australian company that designs and produces fast pyrolysis plants. Dare to Imagine (DTI) is a consulting firm that among other activities has a renewable energy project commercially producing biochar from waste.

Consultancy companies are a second element in the industry, helping firms set up biochar production. For example Biochar Consulting is a Canadian based company offering 'comprehensive technical services to clients who wish to undertake projects or produce or utilize Biocarbon or Biochar' (Biochar Consulting 
2010 , 1). CarbonZero focuses specifically on biochar as 'a team of agricultural consultants who can help firms interested in reaping the multiple benefits of utilizing biochar in their operations' (CarbonZero $2010,1)$. A third kind of company are consultancy (or finance) groups offering carbon offsets through biochar, sometimes alongside biochar production. Thus Crucible Carbon includes biochar amongst the options it advises for how companies can go carbon neutral based on pyrolysis technology, while doing research on next generation pyrolysis. Outback Biochar produces biochar mobile technology, sells biochar in small quantities, and provides consultancy services to assess biochar sites, feedstocks, carbon potential, and financing and profit options. Re:char is 'part technology company and part information source, providing up-to-date information and commentary on the nascent world of biochar' (Re:char $2010,1)$. In other cases, energy and mining companies have started biochar projects. In South Africa, for example, Alterna Energy, a subsidiary of a Canadian company, started a small pyrolysis plant in Mpumalanga Province, with the charcoal sold as fuel and for biochar trials.

These are only examples in a vibrant world of 'start-up' businesses emerging around the financial promise of biochar. That such promise has yet to be realized in full-scale carbon markets gives the industry something of the 'speculative bubble' character of the early internet years, or of parts of the pharmaceutical world. In the absence of such markets, how revenues will actually flow, and to whom, is unproven. Yet the businessification of the industry itself suggests a skewing of benefits in the value chain towards the businesses operating the system, not the farmers implementing it. As in the pharmaceutical industry, biochar-related businesses are also vibrant in filing patents. A large number have been developed, including, for example, a German patent on 'Systems and methods for capturing, isolating and sequestering carbon from $\mathrm{CO} 2$ in the atmosphere in the form of char produced from biomass feedstock' $\left(\right.$ Terra $\left.\operatorname{Preta}^{R} 2011,1\right)$. There is a close association between the scientific community that is producing such patentable technologies and products, and biochar businesses. This is made visible in conferences and indeed very much encouraged under current university research governance regimes, in which impact through business and co-funding though business are highly valued and promoted.

The patenting of biochar concepts and products is proceeding without reference to possible intellectual property claims by farmers who are producing anthropogenic dark earths through indigenous practices. In the case of Amazonian terra preta, it is easy for companies to rule these out by assuming the inhabitants who might otherwise have made them to be of a pre-Columbian era many centuries ago. In the case of African farming, most research and development is blind to the possibility of indigenous dark earth creation practices. This reflects how, as we go on to show, the financialisation and businessification of biochar is shaping the science conducted about it.

\section{Market promise and the disciplining of science}

The challenge of getting biochar into the new carbon economy and markets is disciplining and shaping research into anthropogenic soil improvements associated with ADE. Firstly it channels research towards biochar, and second, it focuses research into biochar on resolving the uncertainties that would get biochar to market - at the expense of its agronomy.

A major stumbling block concerns measurement, reporting and verification. Science is therefore being driven by the need for knowledge, standards and verification of the sequestered carbon's 'durability' in soil, and standards in its production through which durability might be assured. Pyrolysed organic material is known to have a much greater average stability than uncharred organic matter - suggesting a difference in decomposition rates of at least an order of magnitude, and the possibility of long-term 
carbon sinks that could endure for hundreds or even thousands of years (Cheng et al. 2008). But huge uncertainties remain concerning this long-term stability and how it may depend on the precise conditions of pyrolysis, on the nature of the feedstock, on the character of 'background' soils and other factors (Lehmann et al. 2009).

Research is also focusing on the efficiency and effectiveness of different biochar feedstocks and biochar production methods with respect to carbon capture. 'Cradle to grave' lifecycle assessments, for instance, generally find that biochar results in a net reduction in greenhouse gas emissions, as well as being an energetically-efficient use of biomass (Gaunt and Lehmann 2008, Lehmann and Joseph 2009). However they also underline that the climate change mitigation benefits depend on the specific feedstocks and methods of biochar production and use (Schahczenski 2010). The argument that some forms of pyrolisation release other more potent greenhouse gases such as methane has been used to justify research into the advanced pyrolisation technology needed to attract carbon funding. Advanced pyrolisation technology is unlikely to be compatible with biochar production and use among resourcepoor, small-scale farmers.

The requirements of the market are also driving research to explore and establish appropriate regulation, monitoring and evaluation for biochar application and crediting (Collison et al. 2009, Lal 2010). This includes the development of systems for quantifying the carbon benefits; work to reduce uncertainties about permanence of sequestration and 'leakage' from projects (Gaunt and Cowie 2009); and the development of robust certification systems. Again, the latter is proving highly challenging for small-scale systems (Lehmann 2009, Palmer 2009).

In short, many of the questions driving biochar science are thus questions driven more by the carbon market, than by interest in biochar's agronomic potential. The promise of biochar in the market, and the emergence of an industry around it, threatens to far outpace agronomic science. Yet such agronomic science as is being conducted is also being shaped strongly by carbon market logics. This is a departure from the original soil science and ecological interests in the soil conditioning effects of carbon, which were sparked by observations of terra preta/ADE.

Whereas studies of terra preta suggest embracing a holistic paradigm in understanding transformations of soil ecology, the allure of the carbon market has heavily narrowed agronomic and soil science research to the reductive study of biochar applications 'as a fertilizer' with trials over its effectiveness resembling fertilizer trials both in their design and in the anticipated timescales in which effects are anticipated and measured. Terra preta has, in this sense, become re-constructed as 'biochar', and biochar itself is fast being re-constructed as stable 'carbon' of the sort one could apply by the bag - a product entirely commensuralised within the carbon market. As we detail elsewhere (Fairhead et al. forthcoming), those strands of holistic ADE science that continue are largely confined to Amazonian research communities. By 2005 when arguments began to be made that Amazonian research on terra preta was relevant to transfer to Africa, the political-economic context of global carbon market promise already held sway. Thus prominent soil scientists and agronomists in the Amazonian biochar field who expanded their attention to African settings, their partners in African soil science institutions (e.g Sohi and Yeboah 2009), and the new generations of international biochar researchers who joined them, inevitably directed their work in line with carbon market imperatives. The reductionist perspectives that extracted soil carbon from its ecosystemic context fitted neatly with powerful 'nutrient balance' models that have held sway in Africanist soil science since the 1960s, albeit always in tension with agroecological conceptions. Economic metaphors infuse work on nutrient balances, their measurement and 
modelling, imagining African 'soil fertility' as if the soil was simply a bank account (Fairhead and Scoones 2005). Thus viewed, biochar represents simply a new and valuable deposit.

\section{Pilot projects and the disciplining of farmers}

The promise of carbon markets is also inspiring and shaping pilot programmes which aim to make visible the technology's possibility, and to be poised to enact markets when and if they materialise. Given the politics of scale discussed earlier, it is not surprising that many of these focus on small-scale farm settings, including in Africa. Such pilots construct farmers in particular ways: both as 'green actors' who save nature and global climate through enhancing soil carbon sinks, and as 'market winners' who will profit from carbon payments. Yet this ambition is also a disciplining force that relies on farmers to modify and re-imagine their farming and everyday practices according to these new technical and market logics.

A variety of model biochar systems that might achieve multiple wins have been proposed for the conditions of farm households in developing countries. These range from a Kenyan household scale bioenergy/biochar system linking crop wastes with improved pyrolising cooking stoves, to a Brazilian system involving the conversion of slash-and-burn farming to slash-and-char (Lehmann and Joseph 2009, Joseph 2009). Hypothetical models are an important stock-in-trade of current debate about the socio-economic as well as environmental promises of biochar, given the paucity of 'systems in practice' on the ground.

Since around 2005, several hypothetical models have been piloted to provide practical examples of small-scale biochar projects. Most describe themselves as 'trials', illustrating both the novelty and unproven character of biochar applications, and the status of many as simultaneous research sites for the development of biochar science. In African settings, for instance, African Biodiversity Network, Biofuelwatch and Gaia Foundation (2009) listed 19 projects, while others have since begun. They include a project by the French Centre for Rural Innovations in Cote d'Ivoire involving biofuel and biochar trials with farmers on 2,500 hectares of smallholdings, and research projects/trials in Western Kenya linked to Cornell University, targeting 20 households with biochar-producing cookstoves. The business Re:Char is also working in Western Kenya, having partnered with a local farmers' organization to pilot its 'Climate Kiln' with 750 farmers (Re:char 2011). In Senegal, the NGO Pro-Natura is working with French firm JTS seeds to create 'super gardens' involving biochar applications and has established pilot pyrolysis plants and biochar trials there, in Mali and in Niger (Fortier 2010). In Cameroon, the Biochar Fund initiated trials of biochar applications to farmers' maize production, but despite some technical success, failed to follow these through (Ndameu, B.A. and Biofuelwatch 2011). Cocoamasters have been applying biochar to cocoa production in Cameroon, along with testing other low carbon innovations in the supply chain (Cocoamasters 2011).

While most of these cases are NGO-led initiatives, a significant proportion involve business partnerships and almost all are locked into research organisations. The IBI promotes a database and forum for the burgeoning number of small projects and trials around the world to post information and share findings, contributing to a growing global community of experimental practice around biochar.

A number of these projects, as well as the organizations promoting them, claim explicitly to link the climate and soil benefits of biochar applications with farmers' livelihood needs. Poverty alleviation and support to small farmers figure amongst the multiple wins that these pilots are seeking. Thus Pro-Natura, whose topline concern is 'fighting rural poverty' describes how the NGO 'decided to 
encourage the use of its green charcoal as a biochar and has launched pilot projects on its intervention sites..... It is thus possible to render the carbon footprint globally negative (by taking more carbon from the atmosphere than is emitted), while fighting effectively against poverty and hunger' (Pro-Natura 2010). Further examples can be found in the work of WorldStove, an NGO 'committed to creating useful and innovative carbon negative products that increase quality of life for individuals and households around the globe' (Worldstove 2010,1). They have developed and piloted pyrolitic cooking stoves that produce biochar in Uganda, Kenya, Malawi, Burkina Faso, Congo and Niger as well as south-east Asia, arguing that:

..... many of our intended end users live in extreme poverty and cannot afford the wood it costs to cook a single meal. All of our stoves are designed to function using waste agricultural products that cannot normally be used in a standard stove. Not only does this mean that the fuel cost becomes less, it also means that the end product, biochar, is of commercial value. Our stoves can therefore provide a new way to generate income for the end user in addition to being environmentally friendly on the global level (ibid).

What is on offer here is not just a triple win (climate change mitigation, appropriate energy, and agricultural benefits/income), but a fourth: improved health from reduced cooking smoke and indoor air pollution. Indeed as discussed above, economic analyses are finding this kind of small-scale, slow pyrolysis in cooking stoves projects to be more efficient and cost-effective for greenhouse gas emissions reductions than the fast pyrolysis that large plants favour (Pratt and Moran 2010).

Farmers who participate in and enact these pilot schemes become configured as 'green', demonstrators of the prospect of 'saving nature' both locally, through sustainable soil management, and globally, through mitigating climate change. In being such green actors, they also become, it is suggested, 'winners' in multiple ways - saving themselves from their own poverty and ill-being through the use of improved agricultural and cooking technologies, and through access to new income streams from higher farm yields and carbon markets to come. The smiling farmer next to extraordinarily lush crops that has become the iconic publicity image of African biochar trials, splashed on website pages, presumably has not just farming profits but promised carbon profits in his or her pocket.

Yet for farmers to enact these supposed nature-profit synergies, and thus become new green subjects, requires a disciplining of their practices in conformity with biochar schemes and their underlying technological and market logics. Pilot biochar projects select and channel farming, agro-ecological and livelihood practices into singular 'systems' and 'cycles' in which biomass is collected, burned and buried in particular ways. Aspects of local repertoires that do not conform to biochar system logic - the logic developed in hypothetical models, now trialed 'on the ground' - may be sidelined and ignored, or newly targeted as problematic and in need of transformation. Thus existing farming repertoires involving a diversity of burning techniques are often, within biochar pilot logics, homogenized as problematic 'slash and burn', to be quelled and converted to new 'slash and char'. The vast diversity of biomass byproducts that result from farming and everyday practices, and which are put to a myriad uses in village and farming landscapes, are re-labelled as 'agricultural wastes' targeted to feed biochar kilns. The precise effects of such disciplining on livelihoods, ecologies and landscapes, the possible trade-offs as farming practices and biomass use are narrowed and channeled, and how these might be felt by socially-differentiated farmers facing different resource access, gender and labour constraints, are yet to be explored. What is already clear, though, is that biochar pilots are imposing a degree of standardization and singularity on farming repertoires that sits uneasily with the socially- and ecologically-mediated diversity that is such a central feature of most small-scale African farming. 
Analyses of REDD+ are already exploring the channeling of local resource use practices and livelihoods by global carbon logics (e.g. Conant infra). Biochar pilots extend these above-ground issues underground, into farmers' soils. Meanwhile, and in some contrast with REDD+, biochar projects and debate about them have given remarkably little attention to how carbon market revenue streams to farmers might actually be assured. The value-chain and governance considerations to make this particular win' for farmers real seems not just to be low on the radar of the 'businessified' biochar world, but entirely absent.

It will come as no surprise to anyone familiar with rural development projects in Africa, that such projects do not always live up to the hyperbole that surrounds them. The strapline of The Biochar Fund was 'fighting hunger, energy poverty, deforestation and climate change - simultaneously' (Biochar Fund 2010 , 1). The Fund claimed its impact in as in creating 'a synergy that radically changes the livelihoods of some of the world's poorest communities in multiple ways' (ibid). However, Biochar fund is now apparently defunct, amidst accusations of malpractice in Cameroon (Ndameu, B.A. and Biofuelwatch 2011). This case illustrates the dangers of assuming that simply introducing biochar and the discourses surrounding it into a rural African context will discipline farmers into permanently transforming their farming systems and reconfiguring the social institutions that surround them. As our Liberian case shows, some West African societies produce ADE, but in ways deeply embedded in, and inseperable from, social, political and agro-ecological trajectories in historical landscapes. Biochar development projects are unlikely to succeed if they do not tailor their interventions to local societies and their diverse political and historical ecologies.

Returning to the politics of scale, it should be noted that if such small-scale 'green farmer' projects are to add up to globally-significant levels of carbon sequestration, there will have to be a very great many of them. Currently the alternative to the spectre of large-scale, biochar-driven land grabs, is the multiply replicated small-scale 'project grabs', proven through their pilots, which if implemented in the number required, will acquire a degree of standardization that rides roughshod over the diversity of local priorities, livelihoods and landscapes. The logic of the market (and market-oriented research) is likely to work against diversity amongst small-scale projects: As Lehmann points out, 'the distributed nature of biochar systems and the potential for variability between systems create significant opportunities for sustainability, but also hurdles to widespread adoption, regulation and financial viability' (in Cohen 2009, 1). Diverse, context-specific, locally-adapted schemes present major challenges to the verification, certification and standardization that emerging carbon markets require. This adds to the range of trade-offs in biochar scale relevant to green grabbing. These are not just between large, industrial-scale biochar applications that are amenable to the international carbon trade but more likely to involve large-scale land-grabbing, and smaller scale applications. They are also between standardised small-scale applications that discipline farming to be amenable to carbon market logics, and the possibility of more diverse, context specific ways of thinking about and developing biochar applications suited to located practices, landscapes and livelihoods. The political and discursive processes that are constructing biochar as a green commodity are currently ranged heavily against the latter.

\section{Conclusions}

The focus on biochar 'disciplined' by the carbon market and associated economy has therefore produced a particular version of what it is to be 'green'. That the precepts shaping contemporary biochar developments contrast strongly with the farmer perspectives and practices around ADE revealed in our Liberian case, serves to throw their discursive and political-economic shaping into sharp relief. As the case study demonstrated, in the Upper Guinea forest ADE is not only produced through 
heterogenous practices, but continuity, spatial distribution, tenure and agricultural practices are shaped by cultural institutions, kinship, gender relations, social transformation, and even warfare. In short, ADE production is deeply embedded in indigenous historical political ecologies, and is quite inseparable from them. Currently, those arguing for biochar as a 'climate solution' are rather dismissive of the kind of indigenous practices which small farmers are likely to use, arguing that these might well liberate other greenhouse gases during pyrolysis, which more than offset the potential carbon locked in the biochar. Technological research is thus focusing on the development of new kiln technologies to generate 'clean char'; technologies which, however small scale, would still require smallholder agriculture to be integrated with a biochar industry. As we have argued, under such circumstances the logics and associated political-economic processes that shape the capture of any carbon payments is unlikely to favour farmers. The spectre of 'green grabs' becomes very real.

We have argued that contemporary biochar developments are already enacting, and threaten further, forms of green grabbing that extend beyond - and are more subtle and pervasive - than simple appropriation of land. The spectre of land grab associated with the increased valuation of land that a biochar economy might produce is certainly a threat. But the 'green grab' associated with the emergence of biochar within the new era of environmental repair is more than this. Underpinned by commodification/financialisation and businessification, the emergence of biochar shaped by the market for carbon is putting into play a new structuring of relations in which farming is carried out. When the green grab is viewed through the 'political-economic lens' thrown up by accumulation by dispossession it becomes possible to see how farmers might less benefit from the win-win of 'improved fertility' and 'supplemented by financial flows from carbon' than 'labour within the carbon industry' while others make profits from their assets. In this vein, critical concern with the idea of carbon offset markets (Bohm and Dabhi, 2009) needs to go beyond its disguise for 'polluting as usual' but discern the whole assemblage that we have outlined here, and the distributional processes that it is putting into effect.

We have also argued that discursive and science-policy processes are interplaying powerfully with political-economy. These are disciplining the science of biochar, favouring research and development compatible with carbon market logics and needs, at the expense of more agronomic, agro-ecological or even social, political and historical understandings. These are also constructing farmers as newly green actors and market winners provided they align their lives and practices with the logics of the new carbon economy. In these ways, soil carbon is 'chopped out' of its ecosystem and social contexts, revalued as a bit of nature that can be exchanged with seemingly equivalent bits of carbon nature elsewhere.

Some have questioned whether investment in biochar approaches for the long-term can be sustained through this style of market growth (Glover 2009). The governance implications of biochar, along with other forms of geo-engineering the climate, are only just beginning to be raised (Royal Society 2009). Most governments have yet to engage in the debate, let alone establish specific policy positions and frameworks - while global policy frameworks through the UNFCCC are, as we have seen, remarkably non-specific when it comes to biochar. In this governance and policy vacuum, businesses and NGOs alike are pursuing their biochar interests, leaving biochar research, development and trade remarkably vulnerable to the unregulated interplay of private hopes and fears - and unlikely to play to the interests of small farmers.

A set of promises that are running ahead of practice and implementation offers the advantage that political-technical regimes are not yet established and cemented, locked-in through investment and practice. In this article, we have explored the very rapid ways in which such embedding is happening, as financial, commercial, and scientific pressures align along specific pathways. Yet these pathways are, for 
the moment, still unsettled; biochar and its markets are still in their 'pilot' or 'potential' phase. Opportunities to destabilise them may therefore be greater than in more practically-embedded fields of technology and economy, including those with 'green' claims. Biochar has been deemed a disruptive technology to incumbent political-economic regimes locked into unsustainable pathways - of high carbon emission-fuelled economies and unsustainable, inorganic fertilizer-fuelled agriculture. If biochar is to offer alternative pathways to sustainability, it is vital that it does not lock-in to routes, styles and valuations of nature that favour market logics at the expense of local livelihoods and landscapes.

\section{References}

African Governments. 2009. Submission of African Governments to the $5^{\text {th }}$ Session of the Ad Hoc Working Group on Long-term Cooperative Action under the Convention (AWG-LCA 5). Bonn, Germany, March - April 2009.

African Biodiversity Network, Biofuelwatch and the Gaia Foundation. 2009. Biochar Land Grabbing: the impacts on Africa. Available at http://www.biofuelwatch.org.uk/. [Accessed 22 June 2010].

Amonette, J., Lehmann, J. and Joseph, S. 2007. Terrestrial Carbon Sequestration with Biochar: A Preliminary Assessment of its Global Potential. American Geophysical Union, Fall Meeting, San Francisco, 10-14 December.

Biochar Consulting. 2010. Pyrolysis, gasification and biochar: The best local solution to issues of climate, energy and food security. Available at: www.biochar-consulting.com. [Accessed on 24 June 2010].

Biochar Europe. 2010. Objectives and actions. Available at: http://www.biochar-europe.org/. [Accessed on 22 June 2010].

Biochar Fund. 2010. About us. Available at:

http://biocharfund.org/index.php?option=com content\&task=view\&id=14\&ltemid=37. [Accessed on June 22 2010)

Biochar Products. 2010. Homepage. Available at: www.biocharproducts.com. [Accessed on 24 June 2010].

Bohm, S. And S. Dabhi (eds). 2009. Upsetting the Offset: the political economy of carbon markets. London: Mayfly Books.

Bongers, F., Poorter, L., Van Rompaey, R.S.A.R., Parren, M.P.E. 1999. Distribution of Twelve Moist Forest Canopy Tree Species in Liberia and Côte d'Ivoire: Response Curves to a Climatic Gradient. Journal of Vegetation Science 10(3), 371-382.

Borras Jr., Saturnino M., McMichael, Philip and Scoones, Ian. 2010. The politics of biofuels, land and agrarian change: editors' introduction', Journal of Peasant Studies, 37: 4, 575 - 592

CarbonZero. 2010. About us. Available at: http://www.carbonzero.ch/. [Accessed on 23 June 2010]. 
Cheng, C-H, J. Lehmann, and M. Engelhard. 2008. Natural oxidation of black carbon in soils: changes in molecular form and surface charge along a climosequence. Geochimica et Cosmochimica Acta 72,15981610.

Cocoamasters. 2011. Climate friendly. Available at: http://cocoamasters.org. [Accessed on 22 October 2011].

Collison, Martin, Lynn Collison, Ruben Sakrabani, Bruce Tofield, and Zoe Wallage. 2009. Biochar and Carbon Sequestration: A Regional Perspective; A report prepared for East of England Development Agency, Norwich, UK: Low Carbon Innovation Centre, University of East Anglia, April 2009. Available at: http://www.uea.ac.uk/lcic/Biochar. [Accessed on 21 June 2010].

Cohen, J. 2009. Biochar hero, Johannes Lehmann, testifies before the 111th Congress. Available at: http://www.re-char.com/2009/07/09/biochar-hero-johannes-lehmann-testifies-before-the-111thcongress/. [Accessed on 22 October 2011].

Cotula, L., S. Vermeulen, R. Leonard and J. Keeley. 2009. Land Grab Or Development Opportunity? Agricultural Investment and international land deals in Africa. London: IIED

Denman, K. L., Brasseur, G., Chidthaisong, A., Ciais, P., Cox, P. M., Dickinson, R.E., Hauglustaine, D., Heinze, C., Holland, E., Jacob, D., Lohmann, U., Ramachandran, S., da Silva Dias, P. L., Wofsy, S.C. and Zhang, X. 2007. Couplings between Changes in the Climate System and Biogeochemistry. Contribution of Working Group I to the Fourth Assessment Report of the Intergovernmental Panel on Climate Change. In: Solomon, S., Qin, D., Manning, M., Chen, Z., Marquis, M., Averyt, K. B., Tignor, M. and Miller, H. L. (Eds.), Climate Change 2007: The Physical Science Basis. Cambridge, UK and New York, NY, USA: Cambridge University Press.

Fairhead, J., T. Geysbeek, S. E. Holsoe and M. Leach. 2003. African-American Exploration in West Africa: Four Nineteenth-Century Diaries. Bloomington, IN, Indiana University Press.

Fairhead, J and Leach, M. 2009. Amazonian Dark Earths in Africa. In: Woods, W. I. T., Teixeira, W.G., Lehmann, J., Steiner, C. WinklerPrins, A.M.G.A. and Rebellato, L. (eds). 2009. Terra Preta Nova: Wim Sombroek's Dream. Dordrecht: Springer.

Fairhead, J., Leach, M., Amanor, K.S. and Lehmann, J. 2009. Amazonian dark earths in Africa? Economic and Social Research Council Research Grant case for support. Available at: www.stepscentre.org\ouuresearch\biochar. [Accessed on 22 October 2011].

Fairhead, J., M. Leach and K.S Amanor. Forthcoming. Anthropogenic Dark Earths and Africa: a political agronomy of research disjunctures. In: J. Sumberg and J. Thompson (eds) Contested Agronomies. London: Earthscan.

Fairhead, J. And I. Scoones. 2005. Local knowledge and the social shaping of soil investments: critical perspectives on the assessment of soil degradation in Africa. Land Use Policy. 22(1), 33-41.

Fortier, A. 2010. Senegalese Farmers Using Innovative Garden Project to Boost Productivity. Available at: http://www.biochar-international.org/VOA/Senegal. [Accessed on 22 October 2011]. 
Flannery, Tim. 2009. Foreword. In: Lehmann, J. and S. Joseph (eds) Biochar for environmental management: Science and technology. London: Earthscan.

Foucault, M. 2008. The Birth of Biopolitics: Lectures at the College de France, 1978-79. New York: Palgrave Macmillan.

Gaunt, J. and Lehmann, J. 2008. Energy balance and emissions associated with biochar sequestration and pyrolysis bioenergy production. Environmental Science \& Technology. 42, 4152-4158.

Goodall, C. 2008. Ten Technologies to Save the Planet. London: Profile Books

Goodall, C., 2009, Biochar: Much is unknown but this is no reason to rule it out. Available at: http://www.guardian.co.uk/environment/cif-green/2009/mar/24/response-biochar-chris-goodall. [Accessed on 23 June 2010].

Glover, M. 2009. Taking biochar to market: some essential concepts for commercial success. In: Lehmann, J. and S. Joseph (eds) Biochar for environmental management: Science and technology, p. 375392. London: Earthscan.

Gaunt, J. and A. Cowie. 2009. Biochar, greenhouse gas accounting and emissions trading. In: Lehmann, J. and S. Joseph (eds) Biochar for environmental management: Science and technology, p. 317-340. London: Earthscan.

González-Pérez, J. A., González-Vila, F. J., Gonzalo, A. and Knicker, H. 2004. The Effect of Fire on Soil Organic Matter-a Review. Environment International. 30 (6), 855-70

Hansen, James, Makiko Sato, Pushker Kharecha, David Beerling, Robert Berner, Valerie MassonDelmotte, Mark Pagani, Maureen Raymo, Dana Royer and James Zachos. 2008. Target Atmospheric CO2: Where Should Humanity Aim? The Open Atmospheric Science Journal 2 (2008), 217-231. Available at: http://www.columbia.edu/ jeh1/2008/TargetCO2 20080407.pdf. [Accessed on 22 October 2011].

Harvey, D. 2003. The New Imperialism. Oxford: Oxford University Press

Homer-Dixon, T. (ed). 2009. Carbon Shift: How the twin crises of oil depletion and climate change will define the future. Ontario: Random House.

IBI. 2009. Letter to the UK Parliament from the International Biochar Initiative, 23 October 2009. Available at: http://www.biochar-international.org/publications. [Accessed on 26 June 2010].

IBI. 2010. International Biochar Initiative. About us. Available at: http://www.biochar-international.org/. [Accessed 20 June 2010].

IBI. 2011. IBI Update on UNFCCC Negotiations and the Potential Role for Biochar. International Biochar Initiative. Available at: http://www.biochar-international.org/policy/international. [Accessed on October 22 2011].

Igoe, J., K. Neves and D. Brockington. 2010. A Spectacular Eco-Tour around the Historic Bloc: Theorising the Convergence of Biodiversity Conservation and Capitalist Expansion. Antipode 42 (3), 486-512. 
Inman, M. 2010. Planning for plan B. Nature Reports Climate Change. Available at: http://www.nature.com/climate/2010/1001/full/climate.2010.135.html. [Accessed on 22 October 2011].

Joseph, S. 2009. Socio-economic assessment and implementation of small-scale biochar projects. In: Lehmann, J. and S. Joseph (eds) Biochar for environmental management: Science and technology, 359374. London: Earthscan.

Kamsler, V. 2011. Biochar explained. Available at: http://www.newcarboneconomy.info/page3.php. [Accessed on 22 October 2011].

Lal, Rattan. 2010. Beyond Copenhagen: mitigating climate change and achieving food security through soil carbon sequestration. Food Security 2 (2), 196-177.

Lehmann, J., Gaunt, J. and Rondon, M. 2006. Bio-Char Sequestration in Terrestrial Ecosystems - A Review. Mitigation and Adaptation Strategies for Global Change. 11, 403-427.

Lehmann, J. and S. Joseph (eds). 2009. Biochar for environmental management: Science and technology. London: Earthscan.

Lehmann, J., C. Czimczik, D. Laird and S. Sohi. 2009. Stability of biochar in soil. In: Lehmann, J. and S. Joseph (eds) Biochar for environmental management: Science and technology, 183-206. London: Earthscan.

Lenton, T. M. and Vaughan, N. E. 2009. The radiative forcing potential of different climate geoengineering options, Atmospheric Chemistry and Physics 9, 5539-5561.

Leopold, R. S. 1991.. Prescriptive Alliance and Ritual Collaboration in Loma Society, Indiana University, Bloomington. Unpublished PhD Disseration. Indiana University, Bloomington. Available at http://anthropology.si.edu/leopold/ [Accessed on 20 October 2011].

Lohmann, L. 2009. Neoliberalism and the calculable world: the rise of carbon trading. In: Bohm, S. And S. Dabhi (eds) Upsetting the Offset: the political economy of carbon markets, 25-40. London: Mayfly books.

Monbiot, G. 2009a. Woodchips with everything. It's the Atkins plan of the low-carbon world. Available at: http://www.guardian.co.uk/environment/2009/mar/24/george-monbiot-climate-change-biochar. [Accessed on 15 July 2010].

Monbiot, G. 2009b. Charleaders must cool enthusiasm for setting fire to the planet. Available at: http://www.guardian.co.uk/environment/georgemonbiot/2009/mar/27/biochar-monbiot-globalwarming. [Accessed on 15 July 2010].

McKibben, B. 2009. Plants Suck. Orion Magazine. March/April 2009.

Nally, D. 2011. The Biopolitics of Food Provisioning, Transactions of the Institute of British Geographers 36: $37-53$ 
Ndameu, B.A. and Biofuelwatch. 2011. Biochar Fund Trials in Cameroon: Hype and Unfulfilled Promises Available at : http://www.biofuelwatch.org.uk/wp-content/uploads/Biochar-Cameroon-report1.pdf. [Accessed on 14 December 2011].

Palmer, Anne Shudy. 2009. 'Pay Dirt' Charcoal: Financing Local and Global Land Conservation with Carbon Payments for Biochar in Agricultural soils. Available at: http://www.conservationcapitalintheamericas.org/students.html. [Accessed on 24 June 2010].

Pratt, Kimberley Pratt and Dominic Moran. 2010. Evaluating the cost-effectiveness of global biochar mitigation potential. Biomass and Bioenergy 34, 1149-1158.

Pro-Natura 2010. Biochar. Available at: http://www.pronatura.org/index.php?lang=en\&page=biochar. [Accessed on 23 June 2010].

Read, P. 2009. Policy to address the threat of dangerous climate change: A leading role for biochar. In: Lehmann, J. and S. Joseph (eds) Biochar for environmental management: Science and technology, 393401. London: Earthscan.

Re:char. 2010. About us. Available at: http://www.re-char.com/about/. [Accessed on 23 June 2010].

Re:char 2011. Climate kiln. Available at: http://www.re-char.com/what-we-do/climate-kiln/. [Accessed on 22 October 2011].

Roberts, Kelli, Brent Gloy, Stephen Joseph, Norman Scott, and Johannes Lehmann. 2010. Life cycle assessment of biochar systems: Estimating the energetic, economic and climate change potential. Environmental Science \& Technology 44(2), 2010, 827-833.

Royal Society. 2009. Geoengineering the climate: Science, governance and uncertainty. London: The Royal Society.

Schahczenski, J. 2010. Biochar and Sustainable Agriculture. ATTRA-National Sustainable Agriculture Information Service. Available at: www.attra.org/attra-pub/ summaries/summary.php?pub=322, [Accessed on 8 December 2010].

Shackley, Simon, Saran Sohi, Stuart Haszeldine, David Manning and Ondrej Masek. 2009.

Biochar, reducing and removing $\mathrm{CO} 2$ while improving soils: A significant and sustainable response to climate change. Evidence submitted to the Royal Society Geo-engineering Climate Enquiry in December 2008 and April 2009, May 2009. Available at:

www.geos.ed.ac.uk/sccs/biochar/documents/Biochar1page.pdf. [Accessed on 27 June 2010].

Sillitoe, P. 2006. Ethnobiology and applied anthropology: rapprochement of the academic with the practical. Journal of the Royal Anthropological Institute (N.S.), S119-S142.

Sohi, S. and Yeboah, E. 2009. Traditional biochar-based management of tropical soil in subsistence agriculture. In: Lehmann, J and Joseph, S. (eds.) (2009), Biochar for environmental management: science and technology, London: Earthscan. 
Smolker, R. 2010. Charcoal Ain't Gonna Cool the Planet (Duh)! Available at:

http://www.commondreams.org/view/2010/06/08-1. [Accessed on 20 June 2010].

Sullivan, S. forthcoming. Banking nature? The spectacular financialisation of environmental conservation.

Terra Preta ${ }^{\mathrm{R}}$ 2011. Terra Preta: The original (translated from German). Available at: http://www.krischenowski.de/terrapreta/terra-preta-marken-patente.htm. [Accessed on October 22 2011).

TNI. 2009. Biochar, a big new threat to people, land and ecosystems. Available at: http://www.tni.org/article/biochar-big-new-threat-people-land-and-ecosystems. [Accessed on 20 June 2010].

TSBI. 2010. The Society of Biochar Initiatives. Available at: http://www.biocharsoc.org/. [Accessed on 23 June 2010].

VenEarth. 2010. About us. Available at: http://www.venearth.com/. [Accessed on 24 June 2010].

Vince, G. 2009. Interview with James Lovelock, originator of the Gaia hypothesis: One last chance to save mankind. Available at: http://www.ecomall.com/activism/ilinterview.htm. [Accessed on 22 October 2011].

Woolf, D., J.E. Amonette, F. Alayne Street-Perrott, J. Lehmann and S. Joseph. 2010. Sustainable biochar to mitigate global climate change. Nature Communications 1(56).

Worldstove. 2010. About us. Available at: http://worldstove.org/. [Accessed on 24 June 2010].

Zoomers, A. 2010. Globalisation and the foreignisation of space: seven processes driving the current global land grab. Journal of Peasant Studies 37(2), 429-447. 